\title{
Non-invasive confirmation of the identity of tablets by near-infrared spectroscopy
}

\author{
M. Ulmschneider ${ }^{1}$ and E. Pénigault ${ }^{2, *}$ \\ ${ }^{1}$ Pharmaceutical Quality Control and Assurance, F. Hoffmann-La Roche Ltd, CH-4070 Basle, Switzerland \\ ${ }^{2}$ Laboratoire de Photochimie Générale, UMR 7525 du CNRS, ENSCMu, 3 rue Alfred Werner, \\ 68093 Mulhouse Cedex, France
}

\begin{abstract}
Calibration of non-invasive near-infrared (NIR) analysis for measurements in diffuse reflectance and transmittance was conducted to confirm the identity of different film-coated and uncoated tablets. NIR-spectra of both sides of the intact tablets were recorded in diffuse reflectance. The second derivation of the spectra was computed and spectral matching was calibrated. A restricted wavelength range was proposed to recognize the tablets independently of the presentation over the NIR-light beam. For transmittance measurement, the tablets were arranged in groups according to their similarities. All calibrations were tested against an independent set of sample spectra. The NIR-method proved to be fast and effective.
\end{abstract}

Key-words. Fourier transform near-infrared spectroscopy - diffuse reflectance - transmittance - non-invasive tablets analysis identity testing.

\section{Introduction}

Many raw materials are incorporated into a variety of formulations produced by the pharmaceutical industry. The materials may be available as powders, solid or liquid mixtures, or as single substances. Excipients and active ingredients are prepared in a suitable manner. In most cases the active ingredient represents only a small part of the dosage form. Excipients are included for example for dissolution, as colouring agents, antioxidants, dry lubricants, bulk fillers, etc. The tablets are typically manufactured from dry mixtures under very high pressure and at high speed. Each of the materials included in a pharmaceutical formulation must correspond to predefined qualitative and quantitative characteristics. The structure or morphology of active ingredients must be within very narrow tolerance limits. Regulatory approved analytical methods were developed to control the quality of raw materials or mixtures of materials. Absorption in the ultra-violet or visible ranges is typically used for assays in solutions. Titration may also be of interest. Usually quantification of compounds involves HPLC separations with subsequent quantification of the active component. Typical analysis procedures to identify active ingredients inside solid dosage forms require first grinding of the tablet or emptying of the capsule, before conducting chemical or spectroscopic testing. To process the sample aggressive chemicals and standard reagents must be used and subsequently disposed of. In addition to their destructive aspect, such methods are time-consuming.

As they had been asked to simplify routine identity testing, the authors developped a fast NIR spectroscopy application for selected tablets requiring neither chemicals nor sample preparation. NIR would focus on the quality of the tablet as a whole and not only on the identity of the active ingredient which is more specifically confirmed by HPLC or TLC for final decision [1,2,3]. NIR spectra are generally characterized by the superposition and combination of vibrations. Visual evaluation is, therefore, difficult. Differences in spectra of similar substances or products consist merely of slight shifts or small changes in shape of mostly wide absorption bands. For these reasons, NIR spectra are basically evaluated with the aid of chemometrics. It is the application of mathematical procedures for processing, evaluating, and interpreting of large bodies of data, such as NIR spectra. To achieve an identity testing of samples, the function of a chemometric software is to model the possible correlation between the spectral data and the known or defined property of the samples. If this correlation is systematic and validated, it is just, then, possible to confirm or predict the identity of unknown samples by the recording under the same conditions just as for the calibration of the NIR spectrum and the subsequent evaluation by using the available calibrations. The specificity of these calibrations is restricted to modelled substances or products.

Two NIR measurement techniques with appropriate equipment, i.e. diffuse reflectance and transmittance, were considered. Measurements by diffuse reflectance mainly yield information on the surface of the sample: NIR-radiation hardly penetrates into the tablet. The potential of transmittance measurements, which cover a more restricted wavelength range than the hitherto performed diffuse reflectance, was also examined [4,5]. Selected proprietary

*Correspondence and reprints.

Received January 21, 2000; revised April 18, 2000; accepted April 20, 2000. 
tablets and dosages were used for modelling and calibration. Brief information on the composition of the tablets is given in appendix I. Only samples from regular production batches which have been checked by conventional laboratory methods and produced analytical results (in compliance with the specifications for the corresponding product) were used for calibration and validation.

\section{Measurement by diffuse reflectance}

\section{Equipment}

A commercially available spectrometer Rapid Content Analyser 5000 and the corresponding spectra analysis program NSAS/IQ ${ }^{2}$ supplied by FOSS/NIRSystems, were used to record spectra at $4 \mathrm{~nm}$ resolution over the NIR wavelength range from 1100 to $2500 \mathrm{~nm}$ (Foss NIRSystems Europe, Ramgatseweg 25, 4941 VN Raamsdonksveer, The Netherlands). The spectrophotometer was a dispersive scanning monochromator of the grating type. Measurements were made with a horizontal sample desk, the Rapid Content Sampler, in the diffuse reflectance mode. The set-up included a tungsten-halogen source lamp, a single monochromator with a holographic diffraction grating, and 6 uncooled lead sulfide detectors. These were distributed circularly at the bottom of a glass window fitted with an iris for centring the samples. Each sample was placed on this window and centered over the light beam, regardless of direction for oblong tablets or markings. The radiated light penetrated through the bottom of the sample, was absorbed, diffusely reflected, and recorded. A complete spectrum was calculated as the mean of 32 full range scans. Each spectrum was made up of 700 data points, which corresponds to the recording of 700 intensities on the wavelength scale. The second derivative of the spectra were calculated to improve the peak shapes and the resolution of overlapping bands, and reduce instrumental baseline deviations. The influence of differing particle sizes or surface compression was also minimized. Before taking NIR measurements, the operator ensured that the monochromator had reached its operating temperature. To rule out any interfering diffuse reflectance, the window in the NIR sample desk was cleaned with a brush. The repeatability of the measurements was ensured by recording a reference spectrum (ceramic disk) at regular intervals.

\section{Experimental}

It was first required that identification should be possible on both sides of the tablets, and in case of split tablets, at the surface of fracture. The latter case was intended to treat particular quality complains, typically when broken tablets were discovered in original packaging and returned by clients. Seven solid film-coated tablets (Aurorix ${ }^{\circledR} 150 \mathrm{mg}$ and $300 \mathrm{mg}$, Bactrim ${ }^{\circledR} 400 / 80 \mathrm{mg}$ and $800 / 160 \mathrm{mg}$, Dormicum ${ }^{\circledR}$ $7.5 \mathrm{mg}$ and $15 \mathrm{mg}$, Hivid ${ }^{\circledR} 0.750 \mathrm{mg}$ ) and nine uncoated tablets $\left(\operatorname{Lariam}^{\circledR}, \operatorname{Lexotan}^{\circledR} 1.5 \mathrm{mg}, 3 \mathrm{mg}\right.$, and $6 \mathrm{mg}$, Madopar $^{\circledR} 200 / 50 \mathrm{mg}$, Rivotril ${ }^{\circledR} 0.5 \mathrm{mg}$ and $2 \mathrm{mg}$, Valium ${ }^{\circledR}$
$5 \mathrm{mg}$ and $10 \mathrm{mg}$ ) were selected for this calibration. For each product and dosage NIR-spectra of samples from different batches were recorded. Each tablet was examined 4 times: both intact surfaces, followed by both surfaces of fracture of the split tablet. Three sets of spectra were used. One of them was required for calibration. Spectra for calibration were grouped into spectral libraries, which were used directly by the calibration part of the program NSAS/IQ ${ }^{2}$. The second set was used for external validation. The calibration was tested for identification against each spectrum not included into the calibration set. As a rule, 4 regular batches and 5 tablets per batch were selected for each product and dosage. For Dormicum ${ }^{\circledR} 7.5 \mathrm{mg}$ only 2 batches with 10 tablets were available for the present study. A total of 320 tablets were used, i.e. 1280 spectra were recorded. The knowledge base for the multivariate calibration included 216 samples and 864 spectra. The external validation set consisted of 104 samples and 416 spectra. The following rule was applied to select samples for the validation set: the tablets of the 4th batch of each product and dosage were examined for validation. In addition, the spectra of the 5 th tablet of each calibration batch were also examined for validation. In the case of Dormicum ${ }^{\circledR} 7.5 \mathrm{mg}$, the following rule was applied: the 4th, 5th, 9th, and 10th tablet of each batch were examined for validation. The third spectra set was used for specificity testing: both sides of 20 tablets from additional batches were examined for each product and dosage. Example spectra measured in diffuse reflectance of a tablet side of Aurorix ${ }^{\circledR} 150 \mathrm{mg}$, Aurorix ${ }^{\circledR} 300 \mathrm{mg}$, Rivotril $^{\circledR} 0.5 \mathrm{mg}$, and Rivotril ${ }^{\circledR} 2 \mathrm{mg}$ are found in figure 1 .

\section{Results}

A first library called TABLETTE was built up by using the full-range second derivative NIR-spectra contained in the calibration file. The number of tablets and the number of spectra used for the calibration and the validation of the library is given appendix II (products $\mathrm{N}^{0} 1$ to 16 ). The 16 products and dosages were arranged into 20 library entries or product variables. Different variables with corresponding spectra were used to distinguish between sides and core for the 7 film-coated tablets, except for Bactrim ${ }^{\circledR}$ dosages. One variable for both sides and core was sufficient for each of the 9 uncoated tablets. The algorithm for spectral matching of the program NSAS/ $\mathrm{IQ}^{2}$ was used for calibration of the library. The program calculated the mean spectrum and the standard deviation of the spectra for each product variable in the library. The mean spectrum was, then, used as a reference for each product variable and combined with an identification by correlation whose threshold level was first set to a default value of $0.85 \%$. The identity of unknown samples was determined by finding out which mean spectrum in the library yielded the correlation coefficient closest to 1.0. This coefficient can be considered as the cosine of the angle between the spectrum of the unknown and the mean spectrum measured over the same range and with the same number of recorded wavelengths. In the event that none of the correlation coefficients for an unknown sample exceeded the correlation threshold, the program 


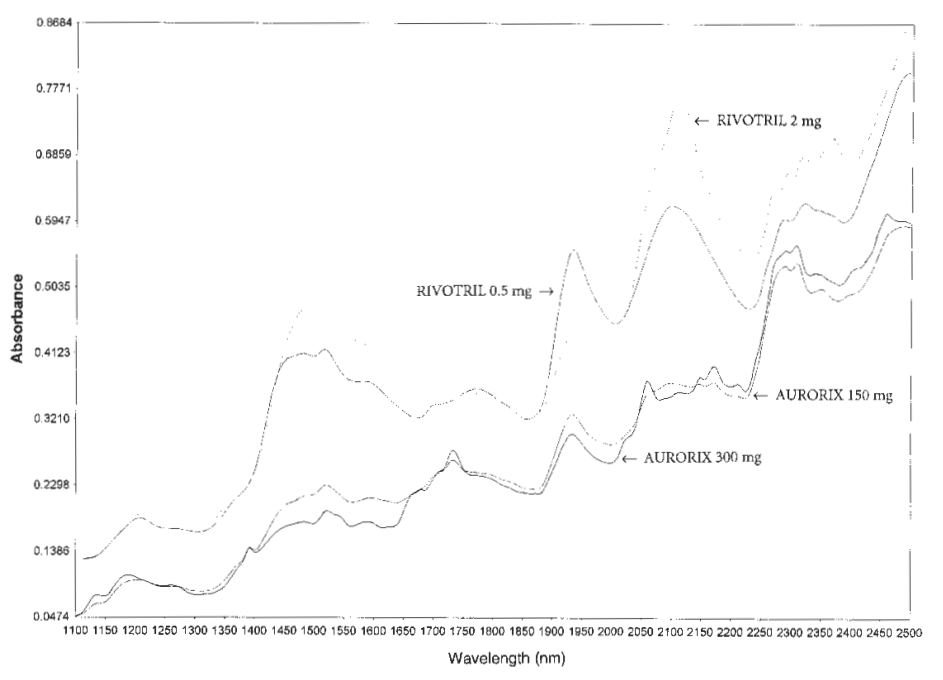

Figure 1.

reported that it failed to identify the sample. The proposed algorithm was sensitive to wavelength shifts and adequate for the identification of products with spectra showing significant differences. However, it was not sensitive to absorbance shifts and may be possibly unable to recognize differences consisting only in variations of peak to peak ratio. Product variable names and calculation parameters of library TABLETTE are summarized in table I. The measurements by diffuse reflectance of the 2 homothetic dosages of Bactrim ${ }^{\circledR}$ were not specific for a discriminating identification of the dosages. The 3 Lexotan ${ }^{\circledR}$ dosages were confusing: Lexotan ${ }^{\circledR} 1.5 \mathrm{mg}$ was conflicting with Lexotan ${ }^{\circledR}$ $3 \mathrm{mg}$. This can be accounted for by the small concentration of the active ingredient: discrimination over the full-range spectra is not possible. Nevertheless, the 3 Lexotan ${ }^{\circledR}$ variables were kept in the library TABLETTE to increase the discrimination of other products and dosages. Thus, a separate library called LEXOTAN was built to identify the 3 Lexotan ${ }^{\circledR}$ dosages. The number of tablets and the number of spectra used for the calibration and the validation of this library are given in appendix II (products $\mathrm{N}^{\circ} 17$ to 22 ). Only the reduced aromatic range of 1600 to $1750 \mathrm{~nm}$ was used, in combination with spectral matching and correlation with a threshold set to $0.85 \%$. Conflicts and false identification of other tablets containing aromatic active ingredients like Valium ${ }^{\circledR}$ and Rivotril ${ }^{\circledR}$ could not be ruled out. As a consequence, Valium ${ }^{\circledR}$ and Rivotril ${ }^{\circledR}$ were added to this library. Details on library LEXOTAN are found in table I. Both TABLETTE and LEXOTAN calibrations were tested against all spectra contained in the spectral data files for the 16 products and dosages. Each spectrum of each product and dosage was correctly identified. The specificity of the calibrations was challenged for successful confirmation of the identity of new samples as the anticipated product or dosage. This was verified with the additional set of spectra recorded for this purpose. The corresponding results with the number of tablets and the number of spectra used to test for specificity is given in appendix III.
It was then suggested to calculate one single model calibration by restricting the wavelength range used for calibration. In addition, identification of the cores was no longer required. Six additional coated tablets and dosages were included: Inhibace ${ }^{\circledR} 0.5 \mathrm{mg}, 2.5 \mathrm{mg}$, and $5 \mathrm{mg}$, Limbitrol ${ }^{\circledR}$ $5 / 12.5 \mathrm{mg}$, Tilcotil ${ }^{\circledR} 20 \mathrm{mg}$, Rohypnol ${ }^{\circledR} 1 \mathrm{mg}$. For each product and dosage, NIR-spectra of samples from different batches were recorded and each side of the tablets was examined. Three sets of spectra were used for calibration, validation, and specificity testing. Sample selection for Inhibace $^{\circledR} 2.5 \mathrm{mg}$ and $5 \mathrm{mg}$, Limbitrol ${ }^{\circledR} 5 / 12.5 \mathrm{mg}$ and Tilcotil ${ }^{\circledR} 20 \mathrm{mg}$ took place just like for Dormicum ${ }^{\circledR} 7.5 \mathrm{mg}$. For Inhibace ${ }^{\circledR} 0.5 \mathrm{mg}$ only 1 batch with 10 tablets was used. A total of 450 tablets were examined, which corresponds to 900 spectra. The knowledge base for the multivariate calibration consisted of 258 samples and 516 spectra. The external validation set included 192 samples and 384 spectra. By starting from the NIR spectra and the composition of the different tablets, it was possible to identify major common bands. Typically, the bands corresponding to the first overtones of $\mathrm{O}-\mathrm{H}$ stretching (around $1450 \mathrm{~nm}$, occurring in starch, lactose, glucose, and water) and $\mathrm{O}-\mathrm{H}$ stretching (around $1940 \mathrm{~nm}$, mainly water) were saturated and, therefore, left out. The new library called TAB2 was based on the full-range second derivative spectra restricted to the following three wavelength ranges : 1116 - $1400 \mathrm{~nm} / 1550$ $1850 \mathrm{~nm} / 1950-2250 \mathrm{~nm}$. The spectra were grouped into 17 product variables, one variable for each dosage, except for Inhibace ${ }^{\circledR}$, whose 3 dosages were arranged into one single product variable. Calibration was performed by spectral matching and correlation with a level set at $0.85 \%$. Variable names and calculation parameters concerning the library TAB2 are summarized in table I. Each product and dosage was discriminated. As expected, the different dosages of Bactrim ${ }^{\circledR}$, Inhibace ${ }^{\circledR}$ and Lexotan ${ }^{\circledR}$ were not discriminated. The calibration was tested for specificity against all spectra contained in the spectral data files for the 22 products and dosages. The number of tablets and the number of spectra 
Table I.

\begin{tabular}{|c|c|c|c|c|}
\hline Library & TABLETTE & LEXOTAN & $T A B 2$ & $T A B 3$ \\
\hline $\begin{array}{l}\text { Mathematical treatment } \\
\text { Selected wavelength } \\
\text { ranges }(\mathrm{nm})\end{array}$ & $\begin{array}{c}\text { second derivation } \\
1116-2484\end{array}$ & $\begin{array}{c}\text { second derivation } \\
1600-1750\end{array}$ & $\begin{array}{c}\text { second derivation } \\
1116-1400 \\
1550-1850 \\
1950-2250\end{array}$ & $\begin{array}{c}\text { second derivation } \\
1116-1400 \\
1550-1850 \\
1950-2250\end{array}$ \\
\hline $\begin{array}{l}\text { Calibration method } \\
\text { Identity correl. threshold } \\
\text { Number of variables } \\
\text { Number of spectra }\end{array}$ & $\begin{array}{c}\text { spectral matching } \\
0.85 \% \\
20 \\
864\end{array}$ & $\begin{array}{c}\text { spectral matching } \\
0.85 \% \\
6 \\
288\end{array}$ & $\begin{array}{c}\text { spectral matching } \\
0.85 \% \\
17 \\
516\end{array}$ & $\begin{array}{c}\text { spectral matching } \\
0.95 \% \\
19 \\
570\end{array}$ \\
\hline \multicolumn{5}{|c|}{$\begin{array}{l}\text { Variables for the film-coated } \\
\text { tablets ( } \mathrm{s}=\text { sides; } \mathrm{c}=\text { cores): }\end{array}$} \\
\hline $\begin{array}{l}\text { Aurorix }{ }^{\circledR} 150 \mathrm{mg} \text { (s) } \\
\text { Aurorix }{ }^{\circledR} 150 \mathrm{mg} \text { (c) } \\
\text { Aurorix }{ }^{\circledR} 300 \mathrm{mg} \text { (s) } \\
\text { Aurorix }{ }^{\circledR} 300 \mathrm{mg} \text { (c) } \\
\text { Bactrim }{ }^{\circledR} 400 / 80 \mathrm{mg} \text { s) }\end{array}$ & $\begin{array}{l}\text { AUR } 150 \\
\text { AUR } 150 \mathrm{~K} \\
\text { AUR } 300 \\
\text { AUR } 300 \mathrm{~K}\end{array}$ & & $\begin{array}{l}\text { AUR } 150 \\
\text { AUR } 300\end{array}$ & $\begin{array}{l}\text { AUR } 150 \\
\text { AUR } 300\end{array}$ \\
\hline $\begin{array}{l}\text { Bactrim }^{\circledR} 800 / 160 \mathrm{mg}(\mathrm{s}) \\
\text { Bactrim }^{\circledR} 400 / 80 \mathrm{mg}(\mathrm{s}+\mathrm{c}) \\
\text { Bactrim }^{\circledR} 800 / 160 \mathrm{mg}(\mathrm{s}+\mathrm{c})\end{array}$ & BACTRIM B & & BACTRIM & BACTRIM \\
\hline $\begin{array}{l}\text { Dormicum }{ }^{\circledR} 7.5 \mathrm{mg} \text { (s) } \\
\text { Dormicum }^{\circledR} 7.5 \mathrm{mg}(\mathrm{c})\end{array}$ & $\begin{array}{l}\text { DOR } 75 \\
\text { DOR } 75 \mathrm{~K}\end{array}$ & & DOR 75 & DOR 75 \\
\hline $\begin{array}{l}\text { Dormicum }^{\circledR} 15 \mathrm{mg} \text { (s) } \\
\text { Dormicum }^{\circledR} 15 \mathrm{mg} \text { (c) }\end{array}$ & $\begin{array}{l}\text { DOR } 15 \\
\text { DOR } 15 \mathrm{~K}\end{array}$ & & DOR 15 & DOR 15 \\
\hline $\begin{array}{l}\operatorname{Hivid}^{\circledR} 0.750 \mathrm{mg} \text { (s) } \\
\text { Hivid }^{\circledR} 0.750 \mathrm{mg} \text { (c) } \\
\text { Inhibace }^{\circledR} 0.5 \mathrm{mg} \text { (s) }\end{array}$ & $\begin{array}{l}\text { HIV } 750 \\
\text { HIV } 750 \mathrm{~K}\end{array}$ & & HIV 750 & HIV 750 \\
\hline $\begin{array}{l}\text { Inhibace }{ }^{\circledR} 2.5 \mathrm{mg}(\mathrm{s}) \\
\text { Inhibace }^{\circledR} 5 \mathrm{mg}(\mathrm{s})\end{array}$ & & & INHI & INHI \\
\hline $\begin{array}{l}\text { Limbitrol }{ }^{\circledR} 5 / 12.5 \mathrm{mg}(\mathrm{s}) \\
\text { Rohypnol }^{\circledR} 1 \mathrm{mg}(\mathrm{s}) \\
\text { Tilcotil }{ }^{\circledR} 20 \mathrm{mg}(\mathrm{s})\end{array}$ & & & $\begin{array}{l}\text { LIMBIT } \\
\text { ROHY } 1 \\
\text { TIL } 20\end{array}$ & $\begin{array}{l}\text { LIMBIT } \\
\text { ROHY } 1 \\
\text { TIL } 20\end{array}$ \\
\hline $\begin{array}{l}\text { Variables for the uncoate } \\
\text { tablets ( } \mathrm{s}=\text { sides; } \mathrm{c}=\text { cores): }\end{array}$ & & & & \\
\hline $\begin{array}{l}\operatorname{Lariam}^{\circledR} \mathrm{BS} / \mathrm{NV}(\mathrm{s}) \\
\text { Lariam }^{\circledR} \mathrm{BS} / \mathrm{NV}(\mathrm{s}+\mathrm{c}) \\
\text { Lexotan }^{\circledR} 1.5 \mathrm{mg}(\mathrm{s})\end{array}$ & LARIAM B & & LARIAM & LARIAM \\
\hline $\begin{array}{l}\text { Lexotan }{ }^{\circledR} 2.5 \mathrm{mg}(\mathrm{s}) \\
\text { Lexotan }^{\circledR} 5 \mathrm{mg}(\mathrm{s})\end{array}$ & & & LEXOTAN & LEXOTAN \\
\hline $\begin{array}{l}\text { Lexotan }{ }^{\circledR} 1.5 \mathrm{mg}(\mathrm{s}+\mathrm{c}) \\
\text { Lexotan }{ }^{\circledR} 2.5 \mathrm{mg}(\mathrm{s}+\mathrm{c}) \\
\text { Lexotan }{ }^{\circledR} 5 \mathrm{mg}(\mathrm{s}+\mathrm{c})\end{array}$ & $\begin{array}{l}\text { LEXO } 15 \\
\text { LEXO } 3 \\
\text { LEXO } 6\end{array}$ & $\begin{array}{l}\text { LEXO } 15 \\
\text { LEXO } 3 \\
\text { LEXO } 6\end{array}$ & & \\
\hline $\begin{array}{l}\text { Madopar }^{\circledR} 200 / 50 \mathrm{mg}(\mathrm{s}) \\
\text { Madopar }^{\circledR} 200 / 50 \mathrm{mg}(\mathrm{s}+\mathrm{c})\end{array}$ & MAD $250 \mathrm{~B}$ & & MAD 250 & MAD 250 \\
\hline $\begin{array}{l}\text { Rivotril }{ }^{\circledR} 0.5 \mathrm{mg}(\mathrm{s}) \\
\text { Rivotril }^{\circledR} 0.5 \mathrm{mg}(\mathrm{s}+\mathrm{c})\end{array}$ & RIVO 5 B & RIVO 5 B & RIVO 5 & RIVO 5 \\
\hline $\begin{array}{l}\text { Rivotril }{ }^{\circledR} 2 \mathrm{mg}(\mathrm{s}) \\
\text { Rivotril }^{\circledR} 2 \mathrm{mg}(\mathrm{s}+\mathrm{c})\end{array}$ & RIVO 2 B & & RIVO 2 & RIVO 2 \\
\hline Tempium ${ }^{\circledR} 100 \mathrm{mg}$ & & & & TEMP \\
\hline $\begin{array}{l}\text { Valium }^{\circledR} 5 \mathrm{mg}(\mathrm{s}) \\
\text { Valium }^{\circledR} 5 \mathrm{mg}(\mathrm{s}+\mathrm{c})\end{array}$ & VAL 5 B & VAL 5 B & VAL 5 & VAL 5 \\
\hline $\begin{array}{l}\text { Valium }{ }^{\circledR} 10 \mathrm{mg}(\mathrm{s}) \\
\text { Valium }^{\circledR} 10 \mathrm{mg}(\mathrm{s}+\mathrm{c})\end{array}$ & VAL $10 \mathrm{~B}$ & VAL $10 \mathrm{~B}$ & VAL 10 & VAL 10 \\
\hline $\begin{array}{l}\text { Xeloda }^{\circledR} 150 \mathrm{mg}(\mathrm{s}) \\
\text { Xeloda }^{\circledR} 500 \mathrm{mg}(\mathrm{s})\end{array}$ & & & & $\begin{array}{l}\text { XELODA } \\
\text { XELODA }\end{array}$ \\
\hline
\end{tabular}

used for the calibration, the validation, and to test for specificity of TAB2 are given in appendices IV and V. Each spectrum of each product and dosage was correctly identified.
The above NIR-application was extended to three additional coated tablets and dosages: Tempium ${ }^{\circledR} 100 \mathrm{mg}$, and Xeloda $^{\circledR} 150$ and $500 \mathrm{mg}$. Neither experimental conditions 
nor calibration parameters were altered. Two new product variables were added to the existing library TAB2 to define library TAB3. The Xeloda ${ }^{\circledR}$ dosages were arranged into one single data set. A spectral matching combined with an identification by correlation (whose threshold level was increased to $0.95 \%$ ) was performed. Table I summarises the calibration parameters and the product variables of library TAB3. The calibration and validation steps required a total of 495 tablets, i.e. 990 spectra were recorded. The complete knowledge base for the multivariate calibration consisted of 285 samples and 570 spectra. The validation set consisted of 210 samples and 420 spectra. The corresponding samples are summarized in appendix VI for Tempium ${ }^{\circledR}$ and Xeloda ${ }^{\circledR}$. The resulting calibration was tested against all spectra contained in the different spectral data files. Each sample of the 25 tablets and dosages was successfully identified as the expected product.

\section{Transmittance measurement}

\section{Equipment}

NIR diffuse reflectance spectroscopy is currently a widely used and reliable tool for quality control in the pharmaceutical industry. Difficulties arise when tablets covered with thick coating materials are examined. It was impossible to gain information on the core of the tablet. NIR by transmittance samples a volume whereas diffuse reflectance NIR merely samples the surface region of solids. NIR light may pass through the entire thickness of tablets if the constituent materials do not absorb in the recorded wavelength range.

The experiments were performed with a Büchi NIRTAB spectrophotometer for the non-destructive tablet analysis, consisting of a FT-NIR spectrometer, a separate autosampler, and the program NIRCAL 3.0 for the multivariate analysis of the spectral data (Büchi Labortechnik AG, Meierseggstrasse 40, Postfach, CH-9230 Flawil 1, Switzerland). This equipment was specially designed for measuring solid samples according to the transmittance principle. The spectrophotometer was a single-beam polarisation interferometer, the interferogram being generated by a system of birefringent quartz prisms which were moving the one in relation to the other. The lighting unit and the corresponding power unit were installed in the autosampler. The lighting unit consisted of a tungsten-halogen lamp. The detection device built into the spectrophotometer was an InGaAs detector at $0{ }^{\circ} \mathrm{C}$ with thermostatic control. The wavelength range was limited from 870 to $1670 \mathrm{~nm}$. The spectrophotometer was linked with an electrical connection to the autosampler and a fibre optical connection with a $1 \mathrm{~mm}$ thick single fibre. The autosampler was equipped with a programmable rotation unit with an exchangeable sample plate. The sample spectra were measured against a reference or white standard (Spectralon ${ }^{\circledR}$ disks supplied by Büchi) whose typical feature was to show no major absorption bands in the NIR range. The thickness of the reference was adjusted according to the transmissivity of the sample. A standard flexible sample plate supplied by Büchi containing 40 circular $5 \mathrm{~mm}$ holes for receiving the tablets and the reference was used at the time of the present study. It was fitted with an adjustable fixing of the samples according to their size and shape. In addition to tablet positions, the sample plate showed openings provided for the reference and for standards. The selected type of sample plate was designed for rapid testing of large sample quantities with varying shape and size, which fitted most of the shapes and sizes of tablets subjected to current analysis.

\section{Experimental}

The substances that had to be identified were separated into different classes called properties in the program NIRCAL 3.0 for the purpose of modelling. A measurement configuration was also defined in combination with the selection of the sample plate. The number of scans needed to compute a spectrum was set to 10 in order to provide the best spectra quality within a reasonable time. Each spectrum was made up of 460 data points, which corresponds to the recording of 460 intensities on the wavenumber scale. Each spectrum was considered as a point in a 460 dimensional spectral space. One single $5 \mathrm{~mm}$ thick reference was used. Example spectra measured in transmittance of Tilcotil ${ }^{\circledR} 20 \mathrm{mg}$, Inhibace ${ }^{\circledR}$ $2.5 \mathrm{mg}$, Inhibace ${ }^{\circledR} 5 \mathrm{mg}$, and Madopar $^{\circledR}$ 200/50 mg are shown in figure 2 . The spectra were arranged into 2 different files. The former was intended for calibration and validation with the program NIRCAL 3.0. The latter was used as an independent challenge set for additional testing of the specificity of the models. In the calibration file, $2 / 3^{\text {rd }}$ of the spectra were selected for calibration, the remaining $1 / 3^{\text {rd }}$ was considered as validation spectra. During automatic calculation of the principal components analysis (PCA) based on a soft modelling algorithm [6,7], the validation spectra were used directly for validation of the models. From the set of components computed during PCA, an optimal number of factors called primary factors in NIRCAL were extracted to describe the spectra down to the limit dictated by noise from the spectrometer. The PCA utilized the redundancy occurring in the spectra without losing important information. The primary factors were statistically independent from each other and orthogonal relative to one another, thus defining new directions in the spectral space. These factors affected the reconstruction of the spectra and fixed the residual values for each product. The first factors were calculated in such a way that they modelled the widest variance possible in the data set. After the PCA was performed, each NIR spectrum was described by the loadings which are the corresponding weightings of each primary factor, and by the residuum spectra which are the difference between the original and the reconstructed spectrum. The spectra were linear combinations of the factors and the loadings down to the residuum spectrum. It was further suggested that a higher selectivity could be achieved with a soft modelling approach. Those primary factors, which correlate best with the properties were selected for the separation of the properties. Thus, from the set of primary factors, secondary factors were selected for optimal separation of the different 


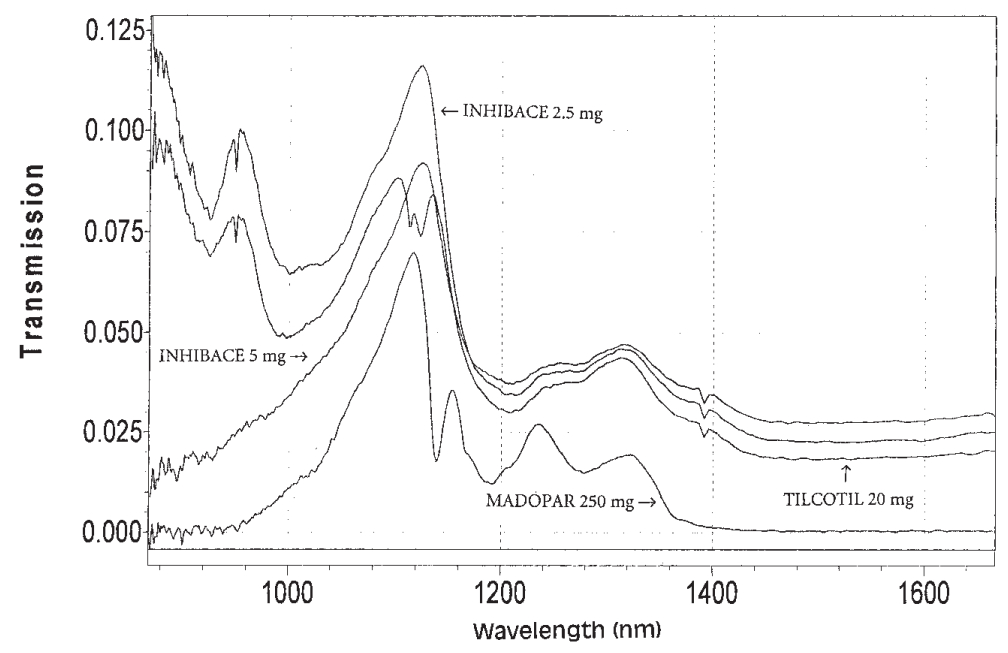

Figure 2

products in combination with a cluster analysis. The secondary factors were not necessarily the factors, which accounted for the greatest variance during the PCA. An additional normalisation of the loadings was automatically performed by introducing Mahalanobis distances to compensate for the stretching or compression of the factor space. The normalisation was performed so that the loading of the spectra kept the same average magnitude as the factor index increased, so as to also identify properties which slightly affect the spectral data and are evidenced by higher factors.

\section{Results}

Due to inadequacy of the hole size of the sample plate available at the time of the experiment, no reproducible values were obtained for Tempium ${ }^{\circledR} 100 \mathrm{mg}$, and Xeloda ${ }^{\circledR} 150$ and $500 \mathrm{mg}$, so that these products were left out. Transmittance measurements through Hivid $^{\circledR}$ tablets were not possible: no measurement configuration led to usable spectra. This can be explained by the presence of excipients such as iron oxide grey and iron oxide black, which yield a dark greyish colour to the coating. An additional dosage of Valium ${ }^{\circledR}$, i.e. $2 \mathrm{mg}$, was considered. For each product and dosage NIRspectra of 60 samples from different regularly approved batches were recorded. As a rule, 40 tablets were used for calibration and internal validation and 20 tablets for the external validation except for Limbitrol ${ }^{\circledR}$, where 50 tablets were taken for calibration and 10 for external validation. A total of 1140 tablets were used. The knowledge base for the multivariate calibration consisted of 770 samples and spectra. The external validation set consisted of 370 samples and spectra. It was not possible to model all products and dosages during one single calibration step. Spectral libraries and calibrations with associated wavelength ranges and specific mathematical pre-treatments were selected empirically to get the best discrimination between the 19 products and dosages. The five libraries obtained and the corresponding calibration parameters are summarized in table II. A first calibration was calculated for the identification of Aurorix ${ }^{\circledR}$ and Rivotril $^{\circledR}$ by using full multiple scattering correction (MSC) from 1000 to $1175 \mathrm{~nm}$. For Bactrim ${ }^{\circledR}$ dosages, the spectra could be separated over the spectral range from 868 to $1177 \mathrm{~nm}$ and a smoothing of the spectra with averages over 9 points. The Lexotan ${ }^{\circledR}$ and Limbitrol ${ }^{\circledR}$ dosages were identified by combining the Savitzky-Golay second derivative (9 points) and a normalisation ( 0 to 1$)$ from 1052 to $1251 \mathrm{~nm}$. To identify Valium ${ }^{\circledR}$ and Dormicum ${ }^{\circledR}$ dosages, a full MSC was performed from 1111 to $1177 \mathrm{~nm}$. Madopar ${ }^{\circledR}$, Tilcotil $^{\circledR}$, and Inhibace ${ }^{\circledR}$ were identified with a normalisation to unit length from 909 to $1177 \mathrm{~nm}$. The 5 calibrations were tested against all spectra contained in the spectral data files for calibration and validation of the relevant products. Each spectrum of each dosage was correctly identified, especially those contained in the challenge set which were not included into the calibration and the validation set. The samples and spectra used for calibration and validation, but also to challenge the calibrations, are shown in appendix VII.

\section{Discussion}

Identification of solid dosages can be performed satisfactorily and without experimental difficulties by diffuse reflectance, a technique now widely diffused in the pharmaceutical industry. More specific difficulties appear when transmittance measurements are considered as an alternative. It was apparent from the above example study that larger amounts of samples were necessary for transmittance identification. This can partly be accounted for by the more reduced wavelength range. An unavoidable drawback is e.g. the loss of characteristic spectral information at $1700 \mathrm{~nm}$, regarding active ingredients which are usually aromatic compounds. Transmittance calibrations required a more extensive mathematical pretreatment and calibration. Although the above results demonstrated the feasibility of 


\section{Original articles}

Table II.

\begin{tabular}{|c|c|c|c|c|c|}
\hline Library identification & $\begin{array}{l}\text { Aurorix }^{\circledR} \\
\text { Rivotril }^{\circledR}\end{array}$ & Bactrim $^{\circledR}$ & $\begin{array}{c}\text { Lexotan }^{\circledR} 1.5,3,6 \\
\text { Limbitrol }^{\circledR}\end{array}$ & $\begin{array}{c}\text { Madopar }^{\circledR} \\
\text { Tilcotil }^{\circledR} \\
\text { Inhibace }^{\circledR} 2.5,5\end{array}$ & $\begin{array}{c}\text { Valium }^{\circledR} 2,5,10 \\
\text { Dormicum }^{\circledR}\end{array}$ \\
\hline Mathematical treatment & full MSC & $\begin{array}{c}\text { smooth average } \\
9 \text { points }\end{array}$ & $\begin{array}{l}1 \text { - second derivative } \\
\text { Savitzky-Golay } 9 \text { pts } \\
2 \text { - normalization } \\
\text { between } 0 \text { to } 1\end{array}$ & $\begin{array}{l}\text { normalization to } \\
\text { unit length }\end{array}$ & full MSC \\
\hline Selected wave-length range $(\mathrm{nm})$ & $1000-1175$ & $868-1177$ & $1052-1251$ & $909-1177$ & $1111-1177$ \\
\hline Number of products & 4 & 2 & 4 & 4 & 5 \\
\hline Number of spectra & 240 & 120 & 240 & 240 & 300 \\
\hline
\end{tabular}

identification by NIR in transmittance, many improvements may help to increase the acceptance of the method in quality control laboratories. For example, the presentation of samples should be made easier and more controllable. In practice, careful consideration should be given to sample presentation in the light beam to avoid secondary diffuse reflectance. Ultimately, the specificity of the prediction made by transmittance measurements compared with that obtained by diffuse reflectance. Thickness of the tablet and thickness of the coating affected the relative absorbance. The coating merely contributed as a weak signal to the full transmittance spectrum. In some cases, however, the coating just stopped the NIR beam. The major advantage of transmittance measurements is that the sample was entirely exposed to the penetrating light beam and, therefore, included far more spectral information on the core of the tablets. Accordingly, it was possible to discriminate between the homothetic dosages of Bactrim ${ }^{\circledR}$ and to separate low dosage Lexotan ${ }^{\circledR}$ and Valium ${ }^{\circledR}$ formulations. That is why transmittance analysis may be better suited for quantitative determinations [8], in so far as the sample holders fit the size of samples.

\section{Conclusions}

Specific and non-invasive techniques of NIR spectroscopy for identity confirmation of selected tablets were developed by using either diffuse reflectance or transmittance with commercially available spectrometers. For both measurements techniques the samples remained unaltered. Under some conditions split tablets could also be identified. Identification by NIR took less than one minute. Sample preparation was not required nor did the method involve the use of chemicals requiring subsequent disposal. External factors exerted minimal effects and this method did not depend on laboratory environment and operator, once adequate measurement configurations were set. The examination of tablets was simple, fast and effective. Identification of any additional dosage or product requires the development of completely new spectral libraries. Adjustments or different distributions of original dosage forms within already existing calibration and validation spectral libraries cannot be ruled out. As a conclusion, near-infrared spectroscopy is an interesting alternative for the identification of solid dosage forms. Due to the advantage of a more representative spectral information when dealing with less homogeneous samples, which is the case of tablet formulations, further exploration of the capabilities of instruments used in transmittance analysis is advisable.

\section{References}

1. Lodder, R.A.; Hieftje, G.M. Applied Spectroscopy 1988, 42(4), 556-558.

2. Morisseau, K. M.; Rhodes, C. T. Pharmaceutical Technologies, Yearbook 1997, 6-11.

3. Buice Jr., R.B.; Pinkston, P.; Lodder, R.A. Applied Spectroscopy 1994, 48(4), 517-524.

4. Scheiwe, M.W.; Schilling, D.; Aebi, P. Pharm. Ind. 1999, 61, 179-183.

5. Reich, G.; Frickel, H. in Proceed. Intnl. Symp. Control. Rel. Bioact. Mater.; Controlled Release Society Inc., 1999, 26.

6. Wold, S.; Esbensen, K.; Geladi, P. Chemometrics and Intelligent Laboratory Systems 1987, 2, 37-52.

7. Griffin, J.; Grummisch, U. in Near-Infrared Spectroscopy; Hildron, K.I.; Isaksson, T.; Naes, T.; Tandberg, A. Eds., London: Ellis Horwood Ltd, 1992, Chapter 13.

8. Eustaquio, A.; Blanco, M.; Jee, R.D.; Moffat, A.C. Analytica Chimica Acta 1999, 383, 283-290. 
Appendix I. Total weights and active ingredients weights of proprietary tablets used in this study.

\begin{tabular}{|c|c|c|c|}
\hline \multirow[t]{2}{*}{ Drug } & \multirow[t]{2}{*}{ Total weight $(\mathrm{mg})$} & \multicolumn{2}{|c|}{ Active ingredient } \\
\hline & & Name & Weight (mg) \\
\hline Aurorix ${ }^{\circledR} 150 \mathrm{mg}$ & 412.00 & Moclobemide & 150.00 \\
\hline Aurorix $^{\circledR} 300 \mathrm{mg}$ & 412.00 & Moclobemide & 300.00 \\
\hline \multirow[t]{2}{*}{ Bactrim $^{\circledR} 400 / 80 \mathrm{mg}$} & 505.00 & Sulfamethoxazole & 400.00 \\
\hline & & Trimethoprim & 80.00 \\
\hline \multirow{2}{*}{ Bactrim $^{\circledR} 800 / 160 \mathrm{mg}$} & 1010.00 & Sulfamethoxazole & 800.00 \\
\hline & & Trimethoprim & 160.00 \\
\hline Dormicum $^{\circledR} 7.5 \mathrm{mg}$ & 205.00 & Midazolam maleate & 10.20 \\
\hline Dormicum $^{\circledR} 15 \mathrm{mg}$ & 208.00 & Midazolam maleate & 20.40 \\
\hline Hivid $^{\circledR} 0.750 \mathrm{mg}$ & 206.00 & Zalcitabine & 0.75 \\
\hline Inhibace $^{\circledR} 0.5 \mathrm{mg}$ & 133.00 & Cilazapril & 0.52 \\
\hline Inhibace $^{\circledR} 2.5 \mathrm{mg}$ & 205.00 & Cilazapril & 2.61 \\
\hline Inhibace $^{\circledR} 5 \mathrm{mg}$ & 205.00 & Cilazapril & 5.22 \\
\hline Lariam $^{\circledR} 250 \mathrm{mg}$ & 493.30 & Mefloquine hydrochloride & 274.09 \\
\hline $\operatorname{Lexotan}^{\circledR} 1.5 \mathrm{mg}$ & 200.00 & Bromazepam & 1.50 \\
\hline Lexotan ${ }^{\circledR} 3 \mathrm{mg}$ & 200.00 & Bromazepam & 3.00 \\
\hline Lexotan ${ }^{\circledR} 6 \mathrm{mg}$ & 200.00 & Bromazepam & 6.00 \\
\hline \multirow[t]{2}{*}{ Limbitrol $^{\circledR} 5 / 12.5 \mathrm{mg}$} & 290.00 & Chlordiazepoxide & 5.20 \\
\hline & & Amitryptyline hydrochloride & 14.57 \\
\hline \multirow{2}{*}{ Madopar $^{\circledR} 200 / 50 \mathrm{mg}$} & 553.00 & L-Dopa Powder & 200.00 \\
\hline & & Benserazide hydrochloride & 57.00 \\
\hline Rivotril $^{\circledR} 0.5 \mathrm{mg}$ & 170.00 & Clonazepam & 0.50 \\
\hline Rivotril $^{\circledR} 2 \mathrm{mg}$ & 170.00 & Clonazepam & 2.00 \\
\hline Rohypnol $^{\circledR} 1 \mathrm{mg}$ & 100.00 & Flunitrazepam & 1.00 \\
\hline Tempium $^{\circledR} 100 \mathrm{mg}$ & 290.00 & Lazabemide hydrochloride & 118.30 \\
\hline Tilcotil $^{\circledR} 20 \mathrm{mg}$ & 205.00 & Tenoxicam & 20.00 \\
\hline Valium $^{\circledR} 5 \mathrm{mg}$ & 170.00 & Diazepam & 5.00 \\
\hline Valium $^{\circledR} 10 \mathrm{mg}$ & 170.00 & Diazepam & 10.00 \\
\hline Xeloda $^{\circledR} 150 \mathrm{mg}$ & 194.50 & Capecitabine & 150.00 \\
\hline Xeloda $^{\circledR} 500 \mathrm{mg}$ & 638.00 & Capecitabine & 500.00 \\
\hline
\end{tabular}

Appendix II. List of the tablets included in the libraries TABLETTE (products No1 to 16) and LEXOTAN (products No17 to 22), with number of samples and spectra (sides and cores) for calibration and validation, with the output of the confirmation of identity.

\begin{tabular}{|c|c|c|c|c|c|c|}
\hline \multirow[t]{2}{*}{$N^{o}$} & \multirow[t]{2}{*}{ Product } & \multirow{2}{*}{$\begin{array}{l}\text { Batch } \\
N^{o}\end{array}$} & \multirow{2}{*}{$\begin{array}{c}\text { Total number } \\
\text { of spectra }\end{array}$} & \multicolumn{2}{|c|}{ Number of samples (spectra) } & \multirow{2}{*}{$\begin{array}{l}\text { Correctly identified } \\
\text { samples (spectra) }\end{array}$} \\
\hline & & & & for calibration & for validation & \\
\hline 1 & Aurorix ${ }^{\circledR} 150 \mathrm{mg}$ & $1 / 2 / 3 / 4$ & $20 / 20 / 20 / 20$ & $4(16) / 4(16) / 4(16) / 0$ & $1(4) / 1(4) / 1(4) / 5(20)$ & $5(20) / 5(20) / 5(20) / 5(20)$ \\
\hline 2 & Aurorix ${ }^{\circledR} 300 \mathrm{mg}$ & $1 / 2 / 3 / 4$ & $20 / 20 / 20 / 20$ & $4(16) / 4(16) / 4(16) / 0$ & $1(4) / 1(4) / 1(4) / 5(20)$ & $5(20) / 5(20) / 5(20) / 5(20)$ \\
\hline 3 & Bactrim $^{\circledR} 400 / 80 \mathrm{mg}$ & $1 / 2 / 3 / 4$ & $20 / 20 / 20 / 20$ & $4(16) / 4(16) / 4(16) / 0$ & $1(4) / 1(4) / 1(4) / 5(20)$ & $5(20) / 5(20) / 5(20) / 5(20)$ \\
\hline 4 & Bactrim $^{\circledR} 800 / 160 \mathrm{mg}$ & $1 / 2 / 3 / 4$ & $20 / 20 / 20 / 20$ & $4(16) / 4(16) / 4(16) / 0$ & $1(4) / 1(4) / 1(4) / 5(20)$ & $5(20) / 5(20) / 5(20) / 5(20)$ \\
\hline 5 & Dormicum ${ }^{\circledR} 7.5 \mathrm{mg}$ & $1 / 2 / 3 / 4$ & $20 / 20 / 20 / 20$ & $3(12) / 3(12) / 3(12) / 3(12)$ & $2(8) / 2(8) / 2(8) / 2(8)$ & $5(20) / 5(20) / 5(20) / 5(20)$ \\
\hline 6 & Dormicum ${ }^{\circledR} 15 \mathrm{mg}$ & $1 / 2 / 3 / 4$ & $20 / 20 / 20 / 20$ & $4(16) / 4(16) / 4(16) / 0$ & $1(4) / 1(4) / 1(4) / 5(20)$ & $5(20) / 5(20) / 5(20) / 5(20)$ \\
\hline 7 & Hivid $^{\circledR} 0.750 \mathrm{mg}$ & $1 / 2 / 3 / 4$ & $20 / 20 / 20 / 20$ & $4(16) / 4(16) / 4(16) / 0$ & $1(4) / 1(4) / 1(4) / 5(20)$ & $5(20) / 5(20) / 5(20) / 5(20)$ \\
\hline 8 & Lariam $^{\circledR} \mathrm{BS} / \mathrm{NV}$ & $1 / 2 / 3 / 4$ & $20 / 20 / 20 / 20$ & $4(16) / 4(16) / 4(16) / 0$ & $1(4) / 1(4) / 1(4) / 5(20)$ & $5(20) / 5(20) / 5(20) / 5(20)$ \\
\hline 9 & Lexotan ${ }^{\circledR} 1.5 \mathrm{mg}$ & $1 / 2 / 3 / 4$ & $20 / 20 / 20 / 20$ & $5(20) / 5(20) / 5(20) / 5(20)$ & $0 / 0 / 0 / 0$ & $5(20) / 5(20) / 5(20) / 5(20)$ \\
\hline 10 & Lexotan ${ }^{\circledR} 3 \mathrm{mg}$ & $1 / 2 / 3 / 4$ & $20 / 20 / 20 / 20$ & $5(20) / 5(20) / 5(20) / 5(20)$ & $0 / 0 / 0 / 0$ & $5(20) / 5(20) / 5(20) / 5(20)$ \\
\hline 11 & Lexotan ${ }^{\circledR} 6 \mathrm{mg}$ & $1 / 2 / 3 / 4$ & $20 / 20 / 20 / 20$ & $5(20) / 5(20) / 5(20) / 5(20)$ & $0 / 0 / 0 / 0$ & $5(20) / 5(20) / 5(20) / 5(20)$ \\
\hline 12 & Madopar $^{\circledR} 200 / 50 \mathrm{mg}$ & $1 / 2 / 3 / 4$ & $20 / 20 / 20 / 20$ & $4(16) / 4(16) / 4(16) / 0$ & $1(4) / 1(4) / 1(4) / 5(20)$ & $5(20) / 5(20) / 5(20) / 5(20)$ \\
\hline 13 & Rivotril ${ }^{\circledR} 0.5 \mathrm{mg}$ & $1 / 2 / 3 / 4$ & $20 / 20 / 20 / 20$ & $4(16) / 4(16) / 4(16) / 0$ & $1(4) / 1(4) / 1(4) / 5(20)$ & $5(20) / 5(20) / 5(20) / 5(20)$ \\
\hline 14 & Rivotril ${ }^{\circledR} 2 \mathrm{mg}$ & $1 / 2 / 3 / 4$ & $20 / 20 / 20 / 20$ & $4(16) / 4(16) / 4(16) / 0$ & $1(4) / 1(4) / 1(4) / 5(20)$ & $5(20) / 5(20) / 5(20) / 5(20)$ \\
\hline 15 & Valium ${ }^{\circledR} 5 \mathrm{mg}$ & $1 / 2 / 3 / 4$ & $20 / 20 / 20 / 20$ & $4(16) / 4(16) / 4(16) / 0$ & $1(4) / 1(4) / 1(4) / 5(20)$ & $5(20) / 5(20) / 5(20) / 5(20)$ \\
\hline 16 & Valium ${ }^{\circledR} 10 \mathrm{mg}$ & $1 / 2 / 3 / 4$ & $20 / 20 / 20 / 20$ & $4(16) / 4(16) / 4(16) / 0$ & $1(4) / 1(4) / 1(4) / 5(20)$ & $5(20) / 5(20) / 5(20) / 5(20)$ \\
\hline 17 & Lexotan ${ }^{\circledR} 1.5 \mathrm{mg}$ & $1 / 2 / 3 / 4$ & $20 / 20 / 20 / 20$ & $4(16) / 4(16) / 4(16) / 0$ & $1(4) / 1(4) / 1(4) / 5(20)$ & $5(20) / 5(20) / 5(20) / 5(20)$ \\
\hline 18 & Lexotan $^{\circledR} 3 \mathrm{mg}$ & $1 / 2 / 3 / 4$ & $20 / 20 / 20 / 20$ & $4(16) / 4(16) / 4(16) / 0$ & $1(4) / 1(4) / 1(4) / 5(20)$ & $5(20) / 5(20) / 5(20) / 5(20)$ \\
\hline 19 & Lexotan ${ }^{\circledR} 6 \mathrm{mg}$ & $1 / 2 / 3 / 4$ & $20 / 20 / 20 / 20$ & $4(16) / 4(16) / 4(16) / 0$ & $1(4) / 1(4) / 1(4) / 5(20)$ & $5(20) / 5(20) / 5(20) / 5(20)$ \\
\hline 20 & Rivotril ${ }^{\circledR} 0.5 \mathrm{mg}$ & $1 / 2 / 3 / 4$ & $20 / 20 / 20 / 20$ & $4(16) / 4(16) / 4(16) / 0$ & $1(4) / 1(4) / 1(4) / 5(20)$ & $5(20) / 5(20) / 5(20) / 5(20)$ \\
\hline 21 & Valium ${ }^{\circledR} 5 \mathrm{mg}$ & $1 / 2 / 3 / 4$ & $20 / 20 / 20 / 20$ & $4(16) / 4(16) / 4(16) / 0$ & $1(4) / 1(4) / 1(4) / 5(20)$ & $5(20) / 5(20) / 5(20) / 5(20)$ \\
\hline 22 & Valium ${ }^{\circledR} 10 \mathrm{mg}$ & $1 / 2 / 3 / 4$ & $20 / 20 / 20 / 20$ & $4(16) / 4(16) / 4(16) / 0$ & $1(4) / 1(4) / 1(4) / 5(20)$ & $5(20) / 5(20) / 5(20) / 5(20)$ \\
\hline
\end{tabular}




\section{Original articles}

Appendix III. List of the tablets from additionnal batches with the numbers of samples and spectra used to test for specificity, with the output of the confirmation of identity.

\begin{tabular}{|c|c|c|c|}
\hline Product & Batch $N^{o}$ & Number of samples (spectra) & Correctly identified samples (spectra) \\
\hline Aurorix ${ }^{\circledR} 150 \mathrm{mg}$ & $1 / 2 / 3 / 4$ & $5(10) / 5(10) / 5(10) / 5(10)$ & $5(10) / 5(10) / 5(10) / 5(10)$ \\
\hline Aurorix ${ }^{\circledR} 300 \mathrm{mg}$ & $1 / 2$ & $10(20) / 10(20)$ & $10(20) / 10(20)$ \\
\hline Bactrim ${ }^{\circledR} 400 / 80 \mathrm{mg}$ & $1 / 2$ & $10(20) / 10(20)$ & $10(20) / 10(20)$ \\
\hline Bactrim $^{\circledR} 800 / 160 \mathrm{mg}$ & $1 / 2 / 3 / 4$ & $5(10) / 5(10) / 5(10) / 5(10)$ & $5(10) / 5(10) / 5(10) / 5(10)$ \\
\hline Dormicum ${ }^{\circledR} 7.5 \mathrm{mg}$ & $1 / 2$ & $10(20) / 10(20)$ & $10(20) / 10(20)$ \\
\hline Dormicum ${ }^{\circledR} 15 \mathrm{mg}$ & $1 / 2 / 3$ & $10(20) / 10(20)$ & $10(20) / 10(20)$ \\
\hline Hivid $^{\circledR} 0.750 \mathrm{mg}$ & $1 / 2$ & $10(20) / 10(20)$ & $10(20) / 10(20)$ \\
\hline Lariam ${ }^{\circledR} \mathrm{BS} / \mathrm{NV}$ & $1 / 2$ & $10(20) / 10(20)$ & $10(20) / 10(20)$ \\
\hline Lexotan ${ }^{\circledR} 1.5 \mathrm{mg}$ & $1 / 2 / 3 / 4$ & $5(10) / 5(10) / 5(10) / 5(10)$ & $5(10) / 5(10) / 5(10) / 5(10)$ \\
\hline $\operatorname{Lexotan}^{\circledR} 3 \mathrm{mg}$ & $1 / 2$ & $10(20) / 10(20)$ & $10(20) / 10(20)$ \\
\hline Lexotan ${ }^{\circledR} 6 \mathrm{mg}$ & $1 / 2 / 3 / 4$ & $5(10) / 5(10) / 5(10) / 5(10)$ & $5(10) / 5(10) / 5(10) / 5(10)$ \\
\hline Madopar ${ }^{\circledR} 200 / 50 \mathrm{mg}$ & $1 / 2$ & $10(20) / 10(20)$ & $10(20) / 10(20)$ \\
\hline Rivotril ${ }^{\circledR} 0.5 \mathrm{mg}$ & $1 / 2$ & $10(20) / 10(20)$ & $10(20) / 10(20)$ \\
\hline Rivotril ${ }^{\circledR} 2 \mathrm{mg}$ & $1 / 2 / 3 / 4$ & $5(10) / 5(10) / 5(10) / 5(10)$ & $5(10) / 5(10) / 5(10) / 5(10)$ \\
\hline Valium ${ }^{\circledR} 5 \mathrm{mg}$ & $1 / 2$ & $10(20) / 10(20)$ & $10(20) / 10(20)$ \\
\hline Valium ${ }^{\circledR} 10 \mathrm{mg}$ & $1 / 2$ & $10(20) / 10(20)$ & $10(20) / 10(20)$ \\
\hline
\end{tabular}

Appendix IV. List of the tablets included in the library TAB2, with number of samples used for calibration and validation, with the output of the confirmation of identity.

\begin{tabular}{|c|c|c|c|c|c|}
\hline Product & Batch $N^{o}$ & total & $\begin{array}{l}\text { Number of samples } \\
\text { for calibration }\end{array}$ & for validation & $\begin{array}{c}\text { Correctly identified } \\
\text { samples }\end{array}$ \\
\hline Aurorix ${ }^{\circledR} 150 \mathrm{mg}$ & $1 / 2 / 3 / 4$ & $5 / 5 / 5 / 5$ & $4 / 4 / 4 / 0$ & $1 / 1 / 1 / 5$ & $5 / 5 / 5 / 5$ \\
\hline Aurorix ${ }^{\circledR} 300 \mathrm{mg}$ & $1 / 2 / 3 / 4$ & $5 / 5 / 5 / 5$ & $4 / 4 / 4 / 0$ & $1 / 1 / 1 / 5$ & $5 / 5 / 5 / 5$ \\
\hline Bactrim ${ }^{\circledR} 400 / 80 \mathrm{mg}$ & $1 / 2 / 3 / 4$ & $5 / 5 / 5 / 5$ & $4 / 4 / 4 / 0$ & $1 / 1 / 1 / 5$ & $5 / 5 / 5 / 5$ \\
\hline Bactrim $^{\circledR} 800 / 160 \mathrm{mg}$ & $1 / 2 / 3 / 4$ & $5 / 5 / 5 / 5$ & $4 / 4 / 4 / 0$ & $1 / 1 / 1 / 5$ & $5 / 5 / 5 / 5$ \\
\hline Dormicum $^{\circledR} 7.5 \mathrm{mg}$ & $1 / 2$ & $10 / 10$ & $6 / 6$ & $4 / 4$ & $10 / 10$ \\
\hline Dormicum ${ }^{\circledR} 15 \mathrm{mg}$ & $1 / 2 / 3 / 4$ & $5 / 5 / 5 / 5$ & $4 / 4 / 4 / 0$ & $1 / 1 / 1 / 5$ & $5 / 5 / 5 / 5$ \\
\hline Hivid $^{\circledR} 0.750 \mathrm{mg}$ & $1 / 2 / 3 / 4$ & $5 / 5 / 5 / 5$ & $4 / 4 / 4 / 0$ & $1 / 1 / 1 / 5$ & $5 / 5 / 5 / 5$ \\
\hline Inhibace ${ }^{\circledR} 0.5 \mathrm{mg}$ & 1 & 10 & 6 & 4 & 10 \\
\hline Inhibace ${ }^{\circledR} 2.5 \mathrm{mg}$ & $1 / 2$ & $10 / 10$ & $6 / 6$ & $4 / 4$ & $10 / 10$ \\
\hline Inhibace $^{\circledR} 5 \mathrm{mg}$ & $1 / 2$ & $10 / 10$ & $6 / 6$ & $4 / 4$ & $10 / 10$ \\
\hline Lariam ${ }^{\circledR} \mathrm{BS} / \mathrm{NV}$ & $1 / 2 / 3 / 4$ & $5 / 5 / 5 / 5$ & $4 / 4 / 4 / 0$ & $1 / 1 / 1 / 5$ & $5 / 5 / 5 / 5$ \\
\hline $\operatorname{Lexotan}^{\circledR} 1.5 \mathrm{mg}$ & $1 / 2 / 3 / 4$ & $5 / 5 / 5 / 5$ & $4 / 4 / 4 / 0$ & $1 / 1 / 1 / 5$ & $5 / 5 / 5 / 5$ \\
\hline $\operatorname{Lexotan}^{\circledR} 3 \mathrm{mg}$ & $1 / 2 / 3 / 4$ & $5 / 5 / 5 / 5$ & $4 / 4 / 4 / 0$ & $1 / 1 / 1 / 5$ & $5 / 5 / 5 / 5$ \\
\hline Lexotan ${ }^{\circledR} 6 \mathrm{mg}$ & $1 / 2 / 3 / 4$ & $5 / 5 / 5 / 5$ & $4 / 4 / 4 / 0$ & $1 / 1 / 1 / 5$ & $5 / 5 / 5 / 5$ \\
\hline Limbitrol $^{\circledR} 5 / 12.5 \mathrm{mg}$ & $1 / 2$ & $10 / 10$ & $6 / 6$ & $4 / 4$ & $10 / 10$ \\
\hline Modopar ${ }^{\circledR} 200 / 50 \mathrm{mg}$ & $1 / 2 / 3 / 4$ & $5 / 5 / 5 / 5$ & $4 / 4 / 4 / 0$ & $1 / 1 / 1 / 5$ & $5 / 5 / 5 / 5$ \\
\hline Rivotrii ${ }^{\circledR} 0.5 \mathrm{mg}$ & $1 / 2 / 3 / 4$ & $5 / 5 / 5 / 5$ & $4 / 4 / 4 / 0$ & $1 / 1 / 1 / 5$ & $5 / 5 / 5 / 5$ \\
\hline Rivotril $^{\circledR} 2 \mathrm{mg}$ & $1 / 2 / 3 / 4$ & $5 / 5 / 5 / 5$ & $4 / 4 / 4 / 0$ & $1 / 1 / 1 / 5$ & $5 / 5 / 5 / 5$ \\
\hline Rohypnol ${ }^{\circledR} 1 \mathrm{mg}$ & $1 / 2 / 3 / 4$ & $10 / 10 / 10 / 10$ & $4 / 4 / 4 / 0$ & $6 / 6 / 6 / 10$ & $10 / 10 / 10 / 10$ \\
\hline Tilcotil ${ }^{\circledR} 20 \mathrm{mg}$ & $1 / 2$ & $10 / 10$ & $6 / 6$ & $4 / 4$ & $10 / 10$ \\
\hline Valium ${ }^{\circledR} 5 \mathrm{mg}$ & $1 / 2 / 3 / 4$ & $5 / 5 / 5 / 5$ & $4 / 4 / 4 / 0$ & $1 / 1 / 1 / 5$ & $5 / 5 / 5 / 5$ \\
\hline Valium ${ }^{\circledR} 10 \mathrm{mg}$ & $1 / 2 / 3 / 4$ & $5 / 5 / 5 / 5$ & $4 / 4 / 4 / 0$ & $1 / 1 / 1 / 5$ & $5 / 5 / 5 / 5$ \\
\hline
\end{tabular}


Appendix V. List of the tablets from additionnal batches with number of samples to test for specificity, with the output of the confirmation of identity.

\begin{tabular}{|c|c|c|c|}
\hline Product & Batch $N^{o}$ & Number of samples & $\begin{array}{c}\text { Correctly identified } \\
\text { samples }\end{array}$ \\
\hline Aurorix ${ }^{\circledR} 150 \mathrm{mg}$ & $1 / 2 / 3 / 4$ & $5 / 5 / 5 / 5$ & $5 / 5 / 5 / 5$ \\
\hline Aurorix ${ }^{\circledR} 300 \mathrm{mg}$ & $1 / 2$ & $10 / 10$ & $10 / 10$ \\
\hline Bactrim $^{\circledR} 400 / 80 \mathrm{mg}$ & $1 / 2$ & $10 / 10$ & $10 / 10$ \\
\hline Bactrim $^{\circledR} 800 / 160 \mathrm{mg}$ & $1 / 2 / 3 / 4$ & $5 / 5 / 5 / 5$ & $5 / 5 / 5 / 5$ \\
\hline Dormicum ${ }^{\circledR} 7.5 \mathrm{mg}$ & $1 / 2$ & $10 / 10$ & $10 / 10$ \\
\hline Dormicum ${ }^{\circledR} 15 \mathrm{mg}$ & $1 / 2 / 3$ & $10 / 5 / 5$ & $10 / 5 / 5$ \\
\hline Hivid $^{\circledR} 0.750 \mathrm{mg}$ & $1 / 2$ & $10 / 10$ & $10 / 10$ \\
\hline Inhibace ${ }^{\circledR} 2.5 \mathrm{mg}$ & $1 / 2$ & $10 / 10$ & $10 / 10$ \\
\hline Inhibace $^{\circledR} 5 \mathrm{mg}$ & 1 & 10 & 10 \\
\hline Lariam ${ }^{\circledR} \mathrm{BS} / \mathrm{NV}$ & $1 / 2$ & $10 / 10$ & $10 / 10$ \\
\hline Lexotan ${ }^{\circledR} 1.5 \mathrm{mg}$ & $1 / 2 / 3 / 4$ & $5 / 5 / 5 / 5$ & $5 / 5 / 5 / 5$ \\
\hline Lexotan ${ }^{\circledR} 3 \mathrm{mg}$ & $1 / 2$ & $10 / 10$ & $10 / 10$ \\
\hline Lexotan $^{\circledR} 6 \mathrm{mg}$ & $1 / 2 / 3 / 4$ & $5 / 5 / 5 / 5$ & $5 / 5 / 5 / 5$ \\
\hline Madopar $^{\circledR} 200 / 50 \mathrm{mg}$ & $1 / 2$ & $10 / 10$ & $10 / 10$ \\
\hline Rivotril $^{\circledR} 0.5 \mathrm{mg}$ & $1 / 2$ & $10 / 10$ & $10 / 10$ \\
\hline Rivotril $^{\circledR} 2 \mathrm{mg}$ & $1 / 2 / 3 / 4$ & $5 / 5 / 5 / 5$ & $5 / 5 / 5 / 5$ \\
\hline Rohypnol ${ }^{\circledR} 1 \mathrm{mg}$ & $1 / 2 / 3 / 4$ & $10 / 10 / 10 / 10$ & $10 / 10 / 10 / 10$ \\
\hline Valium ${ }^{\circledR} 5 \mathrm{mg}$ & $1 / 2$ & $10 / 10$ & $10 / 10$ \\
\hline Valium ${ }^{\circledR} 10 \mathrm{mg}$ & $1 / 2$ & $10 / 10$ & $10 / 10$ \\
\hline
\end{tabular}

Appendix VI. Number of tablets used for calibration and validation of the TEMPIUM and XELODA dosages in the library TAB3.

\begin{tabular}{lccccc}
\hline Product & Batch $N^{o}$ & total & $\begin{array}{c}\text { Number of samples } \\
\text { for calibration }\end{array}$ & for validation & $\begin{array}{c}\text { Correctly identified } \\
\text { samples }\end{array}$ \\
\hline Tempium $^{\circledR} 100 \mathrm{mg}$ & $1 / 2 / 3 / 4$ & $5 / 5 / 5 / 5$ & $3 / 3 / 3 / 3$ & $2 / 2 / 2 / 2$ & $5 / 5 / 5 / 5$ \\
Xeloda $^{\circledR} 150 \mathrm{mg}$ & $1 / 2$ & $5 / 5$ & $3 / 3$ & $2 / 2$ & $5 / 5$ \\
Xeloda $^{\circledR} 500 \mathrm{mg}$ & $1 / 2 / 3$ & $5 / 5 / 5$ & $3 / 3 / 3$ & $2 / 2 / 2$ & $5 / 5 / 5$ \\
\hline
\end{tabular}




\section{Original articles}

Appendix VII. Number of spectra of tablets used for calibration, validation, and to challenge for the different calibrations in transmittance measurement.

\begin{tabular}{|c|c|c|}
\hline Product & $\begin{array}{l}\text { Number of spectra for } \\
\text { - calibration } \\
\text { - validation } \\
\text { - external validation }\end{array}$ & Batch $N^{o}$ (number of spectra) \\
\hline Aurorix ${ }^{\circledR} 150 \mathrm{mg}$ & $\begin{array}{l}28 \\
12 \\
20\end{array}$ & $\begin{array}{c}1(1) / 2(5) / 3(5) / 4(5) / 5(6) / 6(6) \\
7(6) / 8(6) \\
9(3) / 10(6) / 11(6) / 12(5)\end{array}$ \\
\hline Aurorix ${ }^{\circledR} 300 \mathrm{mg}$ & $\begin{array}{l}28 \\
12 \\
20\end{array}$ & $\begin{array}{c}1(6) / 2(6) / 3(5) / 4(5) / 5(6) \\
6(7) / 7(5) \\
8(6) / 9(6) / 10(6) / 11(2)\end{array}$ \\
\hline Bactrim $^{\circledR} 400 / 80 \mathrm{mg}$ & $\begin{array}{l}27 \\
13 \\
20\end{array}$ & $\begin{array}{c}1(10) / 2(6) / 3(6) / 4(5) \\
5(6) / 6(7) \\
7(5) / 8(5) / 9(5) / 10(5)\end{array}$ \\
\hline Bactrim $^{\circledR} 800 / 160 \mathrm{mg}$ & $\begin{array}{l}27 \\
13 \\
20\end{array}$ & $\begin{array}{c}1(10) / 2(6) / 3(4) / 4(7) \\
5(7) / 6(6) \\
7(5) / 8(2) / 9(7) / 10(6)\end{array}$ \\
\hline Dormicum ${ }^{\circledR} 7.5 \mathrm{mg}$ & $\begin{array}{l}22 \\
16 \\
22\end{array}$ & $\begin{array}{c}1(8) / 2(7) / 3(7) \\
4(8) / 5(8) \\
6(8) / 7(7) / 8(7)\end{array}$ \\
\hline Dormicum $^{\circledR} 15 \mathrm{mg}$ & $\begin{array}{l}25 \\
15 \\
20\end{array}$ & $\begin{array}{c}1(4) / 2(5) / 3(5) / 4(5) / 5(6) \\
6(5) / 7(5) / 8(5) \\
9(5) / 10(5) / 11(5) / 12(5)\end{array}$ \\
\hline Inhibace ${ }^{\circledR} 2.5 \mathrm{mg}$ & $\begin{array}{l}26 \\
12 \\
22\end{array}$ & $\begin{array}{c}1(7) / 2(5) / 3(7) / 4(7) \\
5(7) / 6(5) \\
7(7) / 8(5) / 9(5) / 10(5)\end{array}$ \\
\hline Inhibace ${ }^{\circledR} 5 \mathrm{mg}$ & $\begin{array}{l}26 \\
16 \\
18\end{array}$ & $\begin{array}{c}1(8) / 2(8) / 3(10) \\
4(8) / 5(8) \\
6(8) / 7(10)\end{array}$ \\
\hline $\operatorname{Lexotan}^{\circledR} 1.5 \mathrm{mg}$ & $\begin{array}{l}25 \\
15 \\
20\end{array}$ & $\begin{array}{c}1(5) / 2(5) / 3(5) / 4(5) / 5(5) \\
6(5) / 7(5) / 8(5) \\
9(5) / 10(5) / 11(5) / 12(5)\end{array}$ \\
\hline $\operatorname{Lexotan}^{\circledR} 3 \mathrm{mg}$ & $\begin{array}{l}25 \\
15 \\
20\end{array}$ & $\begin{array}{c}1(4) / 2(3) / 3(3) / 4(3) / 5(3) / 6(3) / 7(3) / 8(3) \\
9(3) / 10(3) / 11(3) / 12(3) / 13(3) \\
14(3) / 15(3) / 16(3) / 17(3) / 18(2) / 19(2) / 20(2) / 21(2)\end{array}$ \\
\hline Lexotan ${ }^{\circledR} 6 \mathrm{mg}$ & $\begin{array}{l}25 \\
15 \\
20\end{array}$ & $\begin{array}{c}1(5) / 2(5) / 3(5) / 4(5) / 5(5) \\
6(5) / 7(5) / 8(5) \\
9(5) / 10(5) / 11(5) / 12(5)\end{array}$ \\
\hline Limbitrol ${ }^{\circledR} 5 / 12.5 \mathrm{mg}$ & $\begin{array}{l}31 \\
19 \\
10\end{array}$ & $\begin{array}{c}1(8) / 2(13) / 3(10) \\
4(10) / 5(19) \\
6(10)\end{array}$ \\
\hline Madopar $^{\circledR} 200 / 50 \mathrm{mg}$ & $\begin{array}{l}26 \\
15 \\
19\end{array}$ & $\begin{array}{c}1(3) / 2(3) / 3(3) / 4(3) / 5(3) / 6(5) / 7(3) / 8(3) \\
9(3) / 10(3) / 11(3) / 12(3) / 13(3) \\
14(5) / 15(5) / 16(3) / 17(3) / 18(3)\end{array}$ \\
\hline Rivotril ${ }^{\circledR} 0.5 \mathrm{mg}$ & $\begin{array}{l}25 \\
15 \\
20\end{array}$ & $\begin{array}{c}1(5) / 2(5) / 3(5) / 4(5) / 5(5) \\
6(5) / 7(5) / 8(5) \\
9(10) / 10(5) / 11(5)\end{array}$ \\
\hline Rivotril $^{\circledR} 2 \mathrm{mg}$ & $\begin{array}{l}27 \\
13 \\
20\end{array}$ & $\begin{array}{c}1(5) / 2(8) / 3(7) / 4(7) \\
5(6) / 6(7) \\
7(7) / 8(6) / 9(7)\end{array}$ \\
\hline Tilcotil ${ }^{\circledR} 20 \mathrm{mg}$ & $\begin{array}{l}25 \\
15 \\
20\end{array}$ & $\begin{array}{c}1(5) / 2(5) / 3(5) / 4(5) / 5(5) \\
6(5) / 7(5) / 8(5) \\
9(5) / 10(5) / 11(5) / 12(5)\end{array}$ \\
\hline Valium ${ }^{\circledR} 10 \mathrm{mg}$ & $\begin{array}{l}27 \\
14 \\
19\end{array}$ & $\begin{array}{c}1(7) / 2(7) / 3(7) / 4(6) \\
5(7) / 6(7) \\
7(5) / 8(4) / 9(5) / 10(5)\end{array}$ \\
\hline Valium ${ }^{\circledR} 5 \mathrm{mg}$ & $\begin{array}{l}24 \\
16 \\
20\end{array}$ & $\begin{array}{c}1(4) / 2(4) / 3(4) / 4(4) / 5(4) / 6(4) \\
7(4) / 8(4) / 9(4) / 10(4) \\
11(5) / 12(5) / 13(5) / 14(5)\end{array}$ \\
\hline Valium ${ }^{\circledR} 2 \mathrm{mg}$ & $\begin{array}{l}25 \\
15 \\
20\end{array}$ & $\begin{array}{c}1(5) / 2(5) / 3(5) / 4(5) / 5(5) \\
6(10) / 7(5) \\
8(5) / 9(5) / 10(5) / 11(5)\end{array}$ \\
\hline
\end{tabular}

